\title{
Effect of zinc deficiency on appetite and plasma amino acid concentrations in the rat
}

\author{
By J. C. WALLWORK, G. J. FOSMIRE AND H. H. SANDSTEAD \\ United States Department of Agriculture, Science and Education Administration, Grand \\ Forks Human Nutrition Research Center, Grand Forks, North Dakota, 58202, USA
}

(Received 20 May 1980 - Accepted 10 July 1980)

\begin{abstract}
1. Levels of zinc in liver and plasma of the $\mathrm{Zn}$-depleted rats fluctuated with the feeding cycle and were significantly higher at the bottom than at the top of the cycle. As $\mathrm{Zn}$ deficiency became more severe fluctuations in plasma $\mathrm{Zn}$ diminished. Concentrations of $\mathrm{Zn}$ in liver, in contrast to levels in plasma and femur, were not markedly lowered by day 15 .

2. In contrast to ad lib.-fed (AL) and overnight-fasted (OF) controls, some pair-fed (PF) controls had elevated levels of $\mathbf{Z n}$ in liver and plasma.

3. Intakes of water and food were significantly correlated in $\mathrm{Zn}$-deficient rats. Packed cell volumes were significantly higher for $\mathrm{Zn}$-depleted than for $\mathrm{AL}$ and $\mathrm{PF}$ rats.

4. Food intakes and plasma glucose concentrations were related in $\mathrm{AL}, \mathrm{OF}$ and $\mathrm{PF}$ control rats but not in $\mathrm{Zn}$-deficient rats.

5. At day 15 of $\mathrm{Zn}$ deficiency the order of total plasma amino acid concentrations in the groups of rats was $A L>Z n$-deficient $>$ OF $>$ PF. Many of the differences between the AL and OF groups for individual plasma amino acids also appeared in the $\mathbf{Z n}$-deficient group at the top and bottom of the feeding cycle. Differences in individual amino acid concentrations at the top and bottom of the feeding cycle tended to be opposite in the PF and the $\mathrm{Zn}$-deficient group. Levels of tyrosine and tryptophan in plasma were correlated $(P<0.05)$ with the cyclic feeding pattern of the $\mathrm{Zn}$-deficient group; however, the ratios tryptophan or tyrosine: sum of other large neutral amino acids did not correlate significantly with the eating habits of $\mathrm{Zn}$-deficient rats.
\end{abstract}

The adverse effect of zinc deficiency on the appetite of animals has long been known (Todd et al. 1934). Anorexia is apparent within 2-3 d of the initiation of a severely $\mathrm{Zn}$-deficient diet (Macapinlac et al. 1966; McConnell \& Henkin, 1974). This reduction in food intake is accompanied by a pattern of cyclic feeding in rats that are given a $\mathrm{Zn}$-deficient, high-protein diet (Mills et al. 1969; Chesters \& Quarterman, 1970; Griffith \& Alexander, 1972; Wilkins et al. 1972). The reason for the anorexia and cyclic feeding patterns in $\mathrm{Zn}$ deficiency is unclear.

Reports from a number of laboratories suggested that amino acid levels in plasma might be related to the control of appetite (Peng \& Harper, 1970; Fernstrom et al. 1973; Tagliamonte et al. 1973; Curzon \& Knott, 1974; Pardridge, 1977; Anderson, 1977; Anonymous, 1978; Tews et al. 1979). More specifically levels of tryptophan in plasma correlated with concentrations of tryptophan and serotonin in brain (Fernstrom et al. 1973; Tagliamonte et al. 1973; Curzon \& Knott, 1974). Findings of Anderson (1977) suggested that in plasma ratio tryptophan:other large neutral amino acids influences intake of protein, and plasma tyrosine: other large neutral amino acids influences the intake of energy.

$\mathrm{Zn}$ deficiency impairs amino acid utilization and metabolism (Hove et al. 1937; Hsu et al. $1969 a, b$; Hsu \& Anthony, 1970; Griffith \& Alexander, 1972; Duerre et al. 1977; Fosmire \& Sandstead, 1977). It seemed possible, therefore, that the cyclic feeding patterns of rats given high-protein, $\mathrm{Zn}$-deficient diets might be related to the plasma ratio tryptophan or tyrosine or both: other large neutral amino acids. We therefore measured the amino acid levels in plasma and other factors that are associated with the cyclic feeding. 
MATERIALS AND METHODS

Diet

All rats were given a $200 \mathrm{~g}$ sprayed egg white $/ \mathrm{kg}$, biotin-enriched diet with a $\mathrm{Zn}$ content of less than $1 \mathrm{mg} / \mathrm{kg}$ (Luecke et al. 1968). The diet was modified by the omission of chlortetracycline hydrochloride and the addition of $1.0 \mathrm{~g}$ inositol $/ \mathrm{kg}$ diet (Teklad Mills, Madison, Wisconsin).

\section{Design of Experiment}

Male Long-Evans rats $(55-65 \mathrm{~g})$ which were purchased commercially (Charles River Breeding Laboratory, Wilmington, Massachusetts) were housed individually in Plexiglas cages in a laminar flow rack located in a humidity- and temperature-controlled room $\left(25^{\circ}\right.$, 40-50\% humidity) with 12-h periods of light and dark. Food intake, water consumption and weight changes were measured between 08.00 and 09.00 hours. Wasted food was collected on papers and weighed at the same time. Wastage was taken into account for pair-feeding (PF), because $\mathrm{Zn}$-deficient rats were significantly more wasteful than either $\mathrm{PF}$ $(P<0.01)$ or ad lib. fed AL; $(P<0.02)$ groups.

For the $7 \mathrm{~d}$ stabilization all rats were fed the $\mathrm{Zn}$-deficient diet ad lib. and $25 \mathrm{mg} \mathrm{Zn} / \mathrm{l}$ as zinc acetate in the drinking water. To minimize trace metal contamination silicon stoppers (Rodhelm-Reiss Inc., Ronsell Rubber Products Division, Belle Mead, New Jersey) were used in the water bottles. The rats were assigned to four groups after the stabilization period (day 0). One group was given the $\mathrm{Zn-deficient} \mathrm{diet} \mathrm{ad} \mathrm{lib.} \mathrm{and} \mathrm{distilled} \mathrm{deionized}$ drinking-water (zinc-deficient rats). Three zinc-adequate control groups were fed the zinc-deficient diet plus zinc acetate in their drinking water. Each rat in the first control group was individually pair-fed (PF) an amount of diet that equalled the amount of diet eaten by the $\mathrm{Zn}$-deficient rat on the previous day. The second control group (AL) was fed ad lib. The third control group (OF) was fed ad lib. and fasted overnight before slaughter. The rats were kept on this regimen for either 15 or $20 \mathrm{~d}$. They were then anaesthetized with diethyl ether and bled by cardiac puncture with heparinized (Eli Lilly and Co., Indianapolis, Indiana) syringes. Packed cell volume was measured on a small portion of whole blood. The plasma was quickly separated from the blood cells by centrifugation and refrigerated.

Within $1 \mathrm{~h}$ after cardiac puncture, $0.5 \mathrm{ml}$ plasma was mixed with an equal volume of $100 \mathrm{~g}$ sulphosalicylic acid/1 containing lithium acetate buffer pH $2 \cdot 2$ (Beckman Instruments Inc., Palo Alto, California) and S- $\beta$ (4-pyridylethyl)-L-cysteine (Sigma Chemical Co., St Louis, Missouri) as the internal standard. The mixture was allowed to stand for 60 min at $4^{\circ}$, then centrifuged at $10000 \mathrm{~g}$ for $20 \mathrm{~min}$ at room temperature. The supernatant fractions were clarified through $0.45 \mu \mathrm{m}$ filters (Millipore Corp., Bedford, Massachusetts) and held at $-70^{\circ}$ before the amino acids were determined with an amino acid analyzer (Beckman Model 119CL; Beckman Instruments Inc., Palo Alto, California). Within $1 \mathrm{~h}$ after collection, plasma tryptophan was assayed spectrofluorometrically by the method of Denckla \& Dewey (1967) as modified by Bloxam \& Warren (1974). Within $24 \mathrm{~h}$, refrigerated plasma was assayed for plasma glucose with glucose oxidase (EC 1.1.1.47) and a glucose analyzer (Beckman Model 2; Beckman Instruments Inc., Fullerton, California) as described by Kadish et al. (1968). Bromcresol green was used to determine plasma albumin concentration (Doumas \& Biggs, 1972).

Tissue $\mathrm{Zn}$ was measured by flame atomic absorption spectroscopy (Varian Model AA-6; Varian-Techtron Pty Ltd, Melbourne, Australia). Absorbance was measured at 213.9 nm and the values were compared with those of $\mathrm{Zn}$ solutions prepared from a certified reference solution containing $1000 \mu \mathrm{g} \mathrm{Zn/l} \mathrm{(Apgar,} \mathrm{1972).} \mathrm{Plasma} \mathrm{Zn} \mathrm{was} \mathrm{determined} \mathrm{after} \mathrm{dilution}$ of the plasma with 3 vol. of distilled water. Two methods of ashing tissue and diet samples 
for $\mathrm{Zn}$ analysis were used. Femurs were cleaned of soft tissue with stainless steel scapels, dried overnight at room temperature, stored at $-20^{\circ}$ for $30-60 \mathrm{~d}$, boiled with $30 \mathrm{ml}$ chloroform-methanol $(2: 1 \mathrm{v} / \mathrm{v})$, dried overnight, weighed and then dry-ashed at $450^{\circ}$ in quartz crucibles (Vycor crucibles, Corning Glass, Corning, New York) in a muffle furnace. After complete ashing, $0.35 \mathrm{ml}$ concentrated, high-purity nitric acid (Ultrex, J. T. Baker Chemical Co., Phillipsberg, New Jersey) was added to the bones and the crucibles were returned to the furnace until the ash was oxidized. The resulting white ash was dissolved in $10 \mathrm{ml}$ of $1 \mathrm{M}$-hydrochloric acid and analysed for $\mathrm{Zn}$. Liver was wet ashed as described by Allen et al. (1977). Freeze-dried liver samples $(0.4-0.5 \mathrm{~g})$ were digested in approximately $30 \mathrm{ml}$ of concentrated $\mathrm{HNO}_{3}$ and $0.5 \mathrm{ml}$ concentrated sulphuric acid. The mixture was heated to a gentle boil, until it emitted white fumes. Digestion was completed by addition of $10 \mathrm{ml}$ hydrogen peroxide $(300 \mathrm{ml} / \mathrm{l})$. Both the dry and wet ashing procedures were utilized in the determination of $\mathrm{Zn}$ in the diet and the values obtained were similar $(P<0.0001)$.

Acid-washed glassware was used throughout the study. Mean values and standard deviations are given and the significance of the differences were examined by use of Student's $t$ test or linear regression.

\section{RESULTS}

Weight gain, intake of food and water and food efficiency ratios for the $15 \mathrm{~d}$ experiment are shown in Table 1. Food intakes of $\mathrm{Zn}$-deficient rats was $63.6 \%$ of the intake of $\mathrm{AL}$ control animals and was significantly depressed $(P<0.01)$ at day 4 and later, although values are not shown. The efficiency of food utilization was significantly less for $\mathrm{Zn}$-deficient than for either AL $(P<0.0001)$ or $\mathrm{Zn}$-adequate, PF control rats $(P<0.0002)$. Although the values are not presented comparable results were obtained for the $20 \mathrm{~d}$ experiment. $\mathrm{Zn}$-deficient rats displayed typical symptoms of $\mathrm{Zn}$-deficiency such as alopecia, depigmentation of hair, dermatitis of paws, anorexia, growth retardation and cyclic feeding. Fig. 1 illustrates food consumption, and weight changes of a representative $\mathrm{Zn}$-deficient and $\mathrm{AL}$ control rat and the cyclic feeding pattern of the $\mathrm{Zn}$-deficient rat.

Although values are not presented daily intakes of water and food were closely correlated $(P<0.001)$ for the $\mathrm{Zn}$-deficient rats but not for $\mathrm{AL}$ and $\mathrm{PF}$ rats. However, total water consumption over the $15 \mathrm{~d}$ period was similar for the three groups (Table 1). After $15 \mathrm{~d}$ the $\mathrm{Zn}$-deprived animals had a packed cell volume of $0.439 \pm 0.023$ which was significantly higher than PF $(0.406 \pm 0.038, P<0.02)$ and the AL control $(0.395 \pm 0.016, P<0.001)$ values. OF rats displayed higher packed cell volumes than the $\mathrm{AL}$ group $(P<0.01)$. The differences in packed cell volumes were also evident at $20 \mathrm{~d}$.

The mean ( $\pm \mathrm{SD}$ ) daily $\mathrm{Zn}$ intake was $490 \pm 133 \mu \mathrm{g}$ for PF and $480 \pm 45 \mu \mathrm{g}$ for AL rats. Plasma $\mathrm{Zn}$ concentrations at 15 and $20 \mathrm{~d}$ are shown in Table 2 . After $15 \mathrm{~d}$, plasma $\mathrm{Zn}$ values for $\mathrm{Zn}$-deficient rats, which were eating the least food, were $46.5 \%$ of those for $\mathrm{AL}$ rats and $23.8 \%$ of those for AL-fed rats at the top of the cycle. After $20 \mathrm{~d}$ plasma $\mathrm{Zn}$ values of $\mathrm{Zn}$-deficient rats at the bottom of the feeding cycle were $28.6 \%$ of the values for $\mathrm{AL}$ rats and $18.0 \%$ of values for $A L$ rats at the top of the cycle. The difference between plasma $\mathrm{Zn}$ values at the bottom and top of the feeding cycle was significant at both 15 and $20 \mathrm{~d}$ $(P<0.02)$. Plasma $\mathrm{Zn}$ level of $\mathrm{Zn}$-deficient rats was significantly lower at both the top and bottom of the feeding cycle on day 20 than on day $15(P<0.05)$.

In liver, in contrast to plasma, $\mathrm{Zn}$ levels were not markedly lowered by $15 \mathrm{~d}$ of $\mathrm{Zn}$ deficiency (Table 3). However, liver $\mathrm{Zn}$ levels in $\mathrm{Zn}$-deficient rats apparently reflected the plasma $\mathrm{Zn}$ changes at the top and bottom of the feeding cycle, i.e. the liver $\mathrm{Zn}$ was significantly higher $(P<0.02)$ at the bottom $(97.3 \pm 12.1 \mu \mathrm{g} / \mathrm{g})$ than at the top of the cycle $(75.0 \pm 11.3 \mu \mathrm{g} / \mathrm{g})$. Liver $\mathrm{Zn}$ was significantly higher $(P<0.01)$ in OF $(117.0 \pm 10.9 \mu \mathrm{g} / \mathrm{g})$ than in AL $(91.9 \pm 3.8 \mu \mathrm{g} / \mathrm{g})$ rats. Liver $\mathrm{Zn}$ was approximately $50 \%$ higher in PF than in 


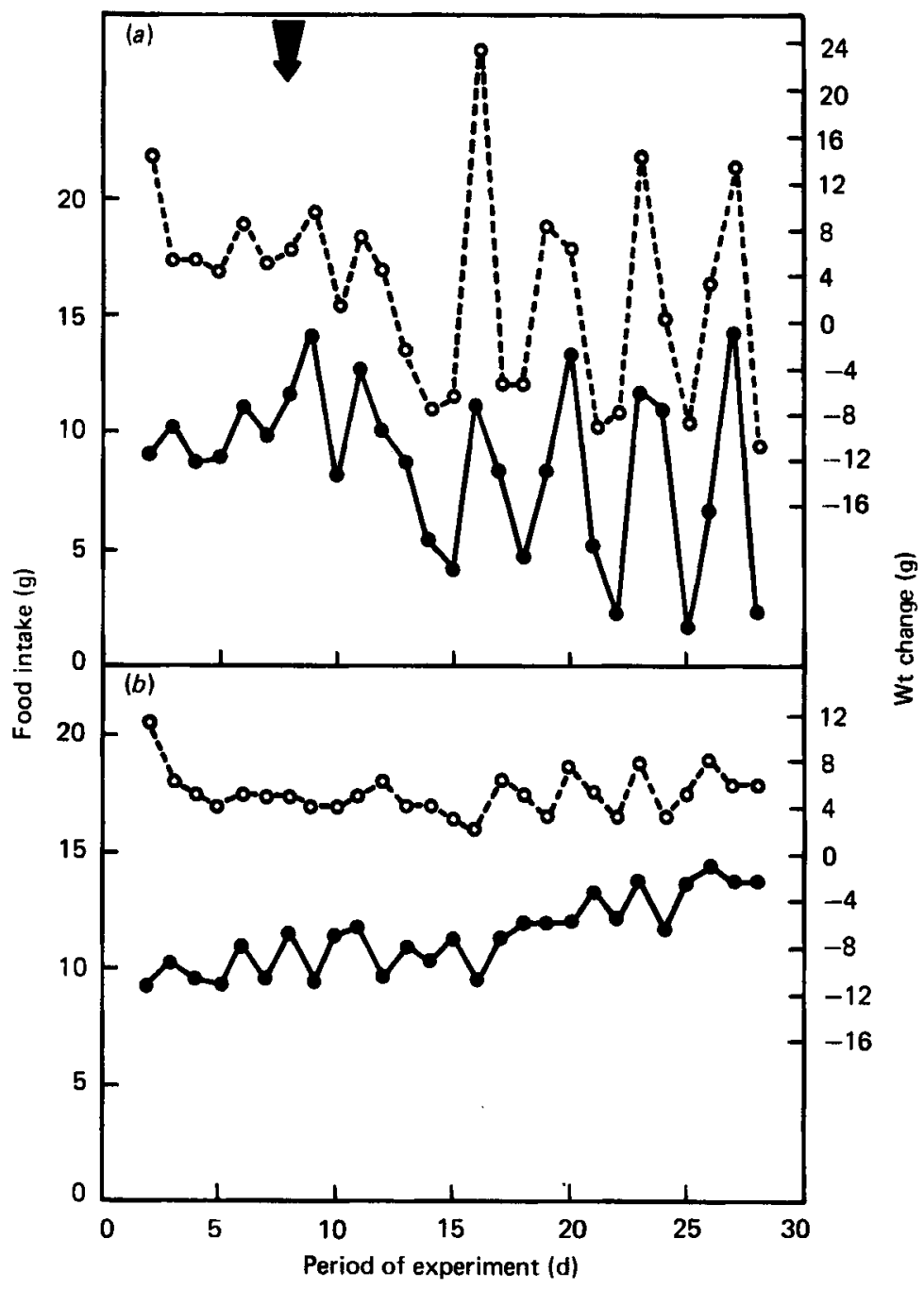

Fig. 1. Weight change $\left(\mathrm{g} ; \mathrm{O}_{---O}\right)$ and food intake $(\mathrm{g} ;-\longrightarrow)$ for a rat given a zinc-deficient diet and distilled water $(a)$ and a rat given a $\mathrm{Zn}$-deficient diet and $25 \mathrm{mg}$ zinc/l in the drinking water $(b)$. From days 0 to 7, both rats were stabilized by feeding a $\mathrm{Zn}$-deficient diet and $25 \mathrm{mg}$ zinc/l in the drinking water. $I$ On day 7 the previously-mentioned regimen was imposed.

$\mathrm{AL}$ or $\mathrm{Zn}$-deficient rats. These values may reflect trends observed in the plasma of PF rats at $15 \mathrm{~d}$, i.e. a number of $\mathrm{PF}$ rats displayed extremely high plasma $\mathrm{Zn}$ concentrations (Table 2).

Correlation was not significant between $\mathrm{Zn}$ level in femur and plasma in any group for either 15 or $20 \mathrm{~d}$. At day 15 femur $\mathrm{Zn}$ in $\mathrm{Zn}$-deprived rats was $117.9 \pm 10.4 \mu \mathrm{g} / \mathrm{g}$, less than half of that for $\mathrm{AL}$ control rats $(266.9 \pm 18.9 \mu \mathrm{g} / \mathrm{g})$, and at day 20 was significantly less $(94.6 \pm 8.1 \mu \mathrm{g} / \mathrm{g}, P<0.001)$ than the $15 \mathrm{~d} \mathrm{Zn-deficient} \mathrm{rats.}$

At day 20 plasma glucose concentrations differed significantly $(P<0.01)$ between the top $(148 \pm 16 \mathrm{~mol} / \mathrm{l})$ and bottom $(119 \pm 11 \mathrm{~mol} / \mathrm{l})$ of the feeding cycle in the PF but not in the $\mathrm{Zn}$-deficient rats $(148 \pm 19$ v. $141 \pm 13 \mathrm{~mol} / 1)$. However, plasma glucose was significantly lower $(P<0.02)$ for $\mathrm{Zn}$-deficient rats at the bottom $(141 \pm 13 \mathrm{~mol} / \mathrm{l})$ of the feeding cycle 
Table 1. Weight gain, intakes of food and water, and food efficiency ratios of Zn-deficient, pair-fed and ad lib.-fed rats for a $15 d$ regimen

(Mean values and standard deviations)

\begin{tabular}{|c|c|c|c|c|c|c|}
\hline \multicolumn{2}{|l|}{ Group } & \multirow{2}{*}{$\begin{array}{l}\text { No. of } \\
\text { rats }\end{array}$} & \multirow{2}{*}{$\begin{array}{l}\text { Wt gain } \\
\text { (g) }\end{array}$} & \multirow{2}{*}{$\begin{array}{l}\text { Total food } \\
\text { intake }(\mathrm{g})\end{array}$} & \multirow{2}{*}{$\begin{array}{l}\text { Total water } \\
\text { intake (ml) }\end{array}$} & \multirow{2}{*}{$\begin{array}{l}\text { Food efficiency } \\
\text { ratio }\end{array}$} \\
\hline Feeding regimen & No. & & & & & \\
\hline $\begin{array}{l}\text { Zn-deficient } \\
\text { Pair-fed } \\
\text { Ad lib.-fed }\end{array}$ & $\begin{array}{l}1 \\
2 \\
3\end{array}$ & $\begin{array}{l}15 \\
15 \\
10\end{array}$ & $\begin{array}{l}17 \cdot 1 \pm 8 \cdot 1 \\
26 \cdot 9 \pm 6 \cdot 0 \\
64 \cdot 3 \pm 11 \cdot 9\end{array}$ & $\begin{array}{l}132 \cdot 1 \pm 12 \cdot 0 \\
125 \cdot 7 \pm 10 \cdot 5 \\
183 \cdot 3 \pm 20 \cdot 3\end{array}$ & $\begin{array}{l}280 \cdot 4 \pm 51 \cdot 9 \\
269 \cdot 2 \pm 45 \cdot 0 \\
296 \cdot 8 \pm 54.9\end{array}$ & $\begin{array}{l}0.128 \pm 0.060 \\
0.214 \pm 0.044 \\
0.349 \pm 0.036\end{array}$ \\
\hline
\end{tabular}

Differences between weight gain values for groups nos. 1 and $2, P<0.02 ; 1$ and $3, P<0.0001 ; 2$ and $3, P<0.0001$.

Differences between total food intake values for groups nos. 1 and $3, P<0.0001 ; 2$ and $3, P<0.0001$.

Differences between food efficiency ratio values for groups nos. 1 and $2, P<0.0002 ; 1$ and $3, P<0.0001 ; 2$ and $3, P<0.0001$.

Table 2. Plasma zinc concentrations in rats given a Zn-deficient diet for 15 or $20 \mathrm{~d}$ with or without $\mathrm{Zn}$ supplementation in the drinking water

(Mean values with their standard deviations)

\begin{tabular}{|c|c|c|c|c|c|c|c|c|}
\hline \multirow{3}{*}{$\begin{array}{c}\text { Period on diet (d)... } \\
\text { Group }\end{array}$} & \multicolumn{8}{|c|}{ Plasma $\mathrm{Zn}(\mu \mathrm{g} / \mathrm{l})$} \\
\hline & \multicolumn{4}{|c|}{15} & \multicolumn{4}{|c|}{20} \\
\hline & $\begin{array}{l}\text { No. of } \\
\text { rats }\end{array}$ & Range & Mean & SD & $\begin{array}{l}\text { No. of } \\
\text { rats }\end{array}$ & Range & Mean & SD \\
\hline \multicolumn{9}{|l|}{ Zn-deficient } \\
\hline $\mathbf{B}$ & 7 & $46 \cdot 0-113 \cdot 7$ & $82 \cdot 7$ & $25 \cdot 0 * t$ & 8 & $24 \cdot 0-60 \cdot 3$ & $47 \cdot 0$ & $12 \cdot 0 \dagger \ddagger$ \\
\hline \multirow{2}{*}{\multicolumn{9}{|c|}{ Pair-fed }} \\
\hline & & & & & & & & \\
\hline B & 7 & $166 \cdot 1-315 \cdot 0$ & 227.8 & $47 \cdot 1$ & 8 & $149.4-606.4$ & $292 \cdot 1$ & 142.4 \\
\hline $\mathbf{T}$ & 7 & $139 \cdot 9-234.5$ & 187.9 & 29.8 & 7 & $157 \cdot 2-483 \cdot 2$ & 221.4 & $119 \cdot 1$ \\
\hline Ad lib.-fed & 10 & $149.7-201 \cdot 0$ & 177.7 & $18 \cdot 1$ & 10 & $135.8-191 \cdot 1$ & $164 \cdot 3$ & $16 \cdot 1$ \\
\hline Overnight-fasted & & & & & 5 & $154 \cdot 2-178$ & 163.0 & 9.9 \\
\hline
\end{tabular}

B, bottom of cycle; $T$, top of cycle.

* Comparison of the top and bottom of the cycle was significant at $15 \mathrm{~d}(P<0.01)$.

$\dagger$ Comparison of the top and bottom of the cycle was significant at $20 \mathrm{~d}(P<0.02)$.

$\ddagger$ Comparison of the bottom of the cycle on days 15 and 20 was significant $(P<0.02)$.

$\S$ Comparison of the top of the cycle on days 15 and 20 was significant $(P<0.03)$.

than for $A L$ rats $(168 \pm 24 \mathrm{~mol} / \mathrm{l})$ and was lowest of all $(103 \pm 18 \mathrm{~mol} / \mathrm{l})$ for $\mathrm{OF}$ rats. These trends were also present after $15 \mathrm{~d}$.

Total amino acid concentrations in plasma are compared in Table 4. In $\mathrm{Zn}$-deficient rats plasma amino acids tended to be lower at the bottom than at the top of the feeding cycle. In PF rats, however, plasma amino acids tended to be higher at the bottom than at the top of the cycle. Relative total plasma amino acid concentrations in the AL and OF groups were similar to values from $\mathrm{Zn}$-deficient rats at the top and bottom of the feeding cycle, i.e. the values tended to be higher at the top than at the bottom of the feeding cycle.

In $\mathbf{A L}$ and $\mathrm{OF}$ groups levels of many individual amino acids were similar to those in the Zn-deficient group at the top and bottom of the feeding cycle respectively. Urea, threonine, serine, asparagine, alanine, citrulline, valine, methionine, isoleucine, leucine, tyrosine, phenylalanine, tryptophan, ornithine and arginine were lower in OF than in AL rats and were lower in $\mathrm{Zn}$-deficient rats at the bottom than at the top of the feeding cycle. This 
Table 3. Liver zinc concentrations in rats given a Zn-deficient diet for $15 d$ with or without $Z n$ supplementation in the drinking water

(Mean values and standard deviations)

\begin{tabular}{|c|c|c|c|c|}
\hline \multirow[b]{2}{*}{ Group } & \multicolumn{4}{|c|}{ Liver zinc ( $\mu \mathrm{g} / \mathrm{g}$ dry $w \mathrm{t})$} \\
\hline & No. of rats & Range & Mean & SD \\
\hline $\begin{array}{l}\text { Zn-deficient } \\
\mathbf{B} \\
\mathbf{T}\end{array}$ & $\begin{array}{l}7 \\
8\end{array}$ & $\begin{array}{l}79 \cdot 1-113.9 \\
62.4-95 \cdot 6\end{array}$ & $\begin{array}{l}97.3 \\
75.0\end{array}$ & $\begin{array}{l}12 \cdot 1^{*} \\
11 \cdot 3^{*}\end{array}$ \\
\hline $\begin{array}{l}\text { Pair-fed } \\
\text { B } \\
\mathrm{T} \\
\text { Ad lib-fed } \\
\text { Overnight-fasted }\end{array}$ & $\begin{array}{r}7 \\
8 \\
10 \\
6\end{array}$ & $\begin{array}{c}119 \cdot 2-182 \cdot 8 \\
104 \cdot 7-148 \cdot 7 \\
86 \cdot 3-96 \cdot 4 \\
96 \cdot 7-125 \cdot 9\end{array}$ & $\begin{array}{r}145.1 \\
123.9 \\
91.9 \\
117.0\end{array}$ & $\begin{array}{c}20 \cdot 3 \dagger \\
14 \cdot 3 \dagger \\
3 \cdot 8 \dagger \\
10 \cdot 9\end{array}$ \\
\hline
\end{tabular}

B, bottom of cycie; $T$, top of cycle.

- Comparison of the top and bottom of the cycle was significant $(P<0.02)$.

$\dagger$ Comparison of pair fed with ad lib. values was significant $(P<0.0001)$.

similarity in plasma amino acid concentrations for the $\mathrm{Zn}$-adequate control and the $\mathrm{Zn}$-deficient rats was not found for glutamic acid and histidine. Glutamic acid levels were depressed in $\mathrm{Zn}$-deficient rats both at the top and bottom of the feeding cycle, but were elevated in OF rats. Glutamic acid was similar in the $\mathrm{Zn}$-deficient rats and in PF controls. Histidine was depressed in OF rats but was elevated both at the top and bottom of the feeding cycle in $\mathrm{Zn}$-deficient rats. Apart from glutamic acid, alanine, tyrosine and histidine, individual amino acids in PF rats were higher at the bottom than the top of the feeding cycle; this was in contrast to the $\mathrm{Zn}$-deficient rats.

The ratio, plasma tryptophan: other large neutral amino acids did not differ significantly among groups (Table 5). The ratio, plasma tyrosine:phenylalanine, however, was significantly lower in $\mathrm{PF}$ and $\mathrm{OF}$ rats than in the $\mathrm{Zn}$-deficient and $\mathrm{AL}$ animals. Plasma tyrosine:phenylalanine also differed significantly between the top and bottom of the cycle for PF but not for $\mathrm{Zn}$-deficient rats. Trends were similar in plasma tyrosine:other large neutral amino acids.

Plasma albumin concentrations for all groups were within normal range at day 15 but were significantly depressed for the $\mathrm{Zn}$-deficient group $(30 \cdot 8 \pm 1 \cdot 1 \mathrm{~g} / \mathrm{l}, P<0.001)$ at day 20 .

\section{DISCUSSION}

Young male rats given a high-protein, $\mathrm{Zn}$-deficient diet displayed typical signs of $\mathrm{Zn}$ deficiency including anorexia and cyclic feeding within 3-4 d. Intakes of water and food were correlated closely. Packed cell volumes were significantly higher in $\mathrm{Zn}$-deficient than in AL and PF control rats. This is in agreement with previous studies, which found increased packed cell volumes in $\mathrm{Zn}$-deficient rats (Macapinlac et al. 1966; Apgar, 1975). This haemoconcentration effect may be due to dehydration caused by zinc deficiency (McKenzie et al. 1975).

In $15 \mathrm{~d}$ of deficiency, femur $\mathrm{Zn}$ fell to less than half the $\mathrm{AL}$ control values. Plasma $\mathrm{Zn}$ fell similarly and fluctuated with the feeding cycle. The correlation between the amount of food consumed and plasma $\mathrm{Zn}$ levels of rats given a high protein $\mathrm{Zn}$-deficient diet agrees with a report by Chesters \& Quarterman (1970). We observed a similar relationship; liver $\mathrm{Zn}$ reflected both plasma $\mathrm{Zn}$ and food intake in $\mathrm{Zn}$ deficient rats, i.e. liver $\mathrm{Zn}$ levels were significantly lower at the top than at the bottom of the feeding cycle. 
Zinc, appetite and plasma amino acids



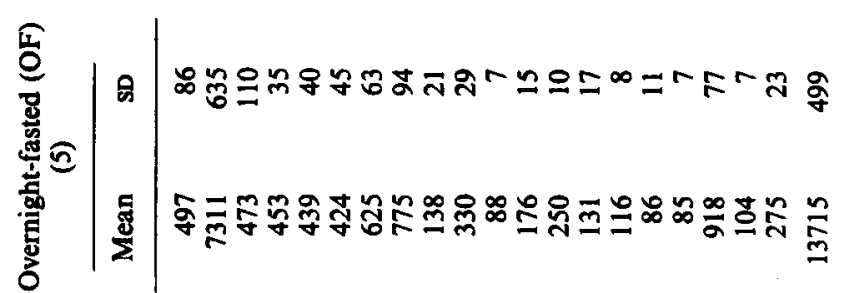



迅

จิ

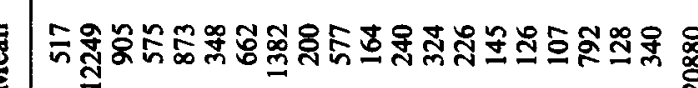

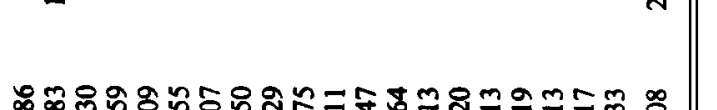

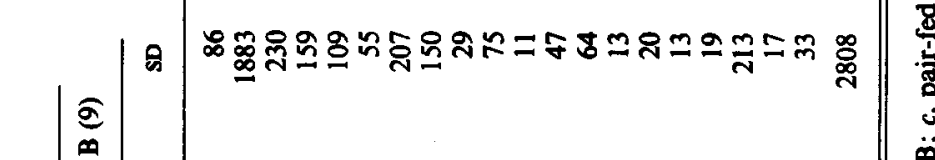



$\sum$

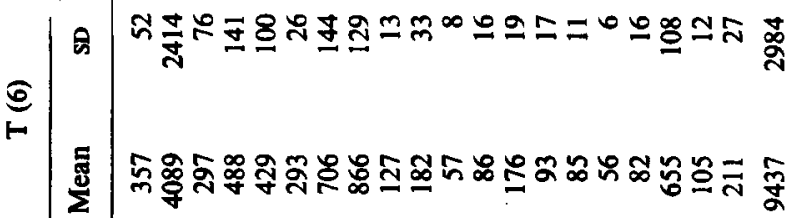

崖

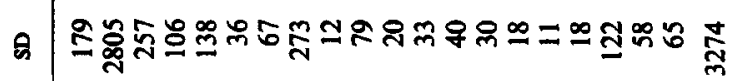

ล

(

苞

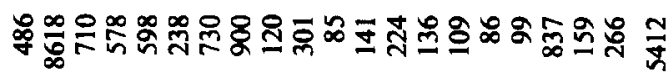

密

2

$\operatorname{niz} 2$

$\infty \approx$

30

$\underline{8}^{a}$

$\stackrel{6}{1}$



(1) 
Table 5. Plasma tyrosine:phenylalanine, plasma tyrosine: sum of the other large neutral amino acids $(N A A)$ and plasma tryptophan:other large neutral amino acids after $15 d$ of the feeding regimen

\begin{tabular}{|c|c|c|c|c|c|c|c|}
\hline \multirow[b]{2}{*}{ Group } & \multirow{2}{*}{$\begin{array}{l}\text { No. of } \\
\text { rats }\end{array}$} & \multicolumn{2}{|c|}{ Tyrosine:phenylalanine ${ }^{a, c, d, g}$} & \multicolumn{2}{|c|}{ Tyrosine: NAA $^{c}$} & \multicolumn{2}{|c|}{ Tryptophan: $\mathrm{NAA}^{d, g}$} \\
\hline & & Mean & SD & Mean & SD & Mean & SD \\
\hline Zn-deficient & 15 & $1 \cdot 355$ & 0.264 & $0 \cdot 161$ & 0.027 & 0.061 & 0.014 \\
\hline B & 9 & $1 \cdot 265$ & 0.265 & $0 \cdot 161$ & 0.034 & 0.055 & 0.013 \\
\hline $\mathrm{T}$ & 6 & 1.489 & 0.195 & $0 \cdot 160$ & 0.017 & 0.070 & 0.011 \\
\hline Pair-fed & 15 & 0.937 & 0.212 & $0 \cdot 134$ & 0.035 & 0.048 & 0.008 \\
\hline B & 9 & 0.824 & 0.228 & $0 \cdot 116$ & 0.018 & 0.046 & 0.007 \\
\hline $\mathbf{T}$ & 6 & $1 \cdot 107$ & 0.228 & $0 \cdot 162$ & 0.038 & 0.050 & 0.009 \\
\hline Ad-lib.-fed & 10 & $1 \cdot 573$ & 0.336 & 0.164 & 0.040 & 0.068 & 0.012 \\
\hline Overnight-fasted & 5 & $1 \cdot 130$ & 0.155 & $0 \cdot 130$ & 0.013 & 0.062 & 0.007 \\
\hline
\end{tabular}

B, bottom of cycle; T, top of cycle; a, AL v. OF; $b$, Zn-deficient T $v$. Zn-deficient B; $c$, pair-fed T $v$. pair-fed B; $d, \mathrm{Zn}$-deficient $v$. AL; $e, \mathrm{Zn}$-deficient $v$. PF; $f$, Zn-deficient $v$. OF; $g, \mathrm{AL} v$. PF; $h$, PF $v$. OF.

$a, b, c, d, e, f, g, h$; differences between groups are significant $P<0.05$.

The extremely high levels of plasma $\mathrm{Zn}$ observed in some PF, Zn-adequate controls might be related to tissue catabolism caused by starvation (Henry \& Elmes, 1975). Spencer \& Samachson (1970) suggested that the $\mathrm{Zn}$ in the zincuria of prolonged starvation is from the liver. In our rats, however, $\mathrm{Zn}$ in the liver of PF controls was elevated approximately $50 \%$, rather than depressed; apparently excess $\mathrm{Zn}$ was from another source. Possibly muscle breakdown is involved in the metabolic response to starvation, as in response to injury (Cuthbertson et al. 1972).

Values for plasma glucose for PF, AL and OF $\mathrm{Zn}$-adequate controls, confirms that under normal conditions plasma glucose correlates closely with food intake. In Zn-deficient rats, however, plasma glucose and food intake were not correlated. This difference might be related to changes in the release of or response of $\mathrm{Zn}$-deficient rats to insulin (Quarterman et al. 1966; Boquist \& Lernmark, 1969; Huber \& Gershoff, 1973). Chesters \& Quarterman (1970) reported that an eating pattern differed between $\mathrm{Zn}$-deficient (nibblers) and the PF control rats (meal eaters), which might explain some of the differences in plasma glucose between those groups.

Total plasma amino acids were significantly higher in $\mathrm{Zn}$-deficient rats than in PF, $\mathrm{Zn}$-adequate controls, which agrees with the findings of Griffith \& Alexander (1972). Many of the differences for individual amino acids between the top and bottom of the feeding cycle in $\mathrm{Zn}$-deficient rats were mirrored by a comparison of $\mathrm{AL}$ and OF control rats; when rats ate food the level of most amino acids in plasma increased, but when rats fasted the level decreased, exceptions being glutamic acid and histidine. For the PF. Zn-adequate controls the trend was reversed; levels of most plasma amino acids were depressed at the top and elevated at the bottom of the feeding cycle. In PF rats the plasma amino acids probably increased at the bottom of the feeding cycle because body protein was degraded and amino acids were released into the plasma as reported during starvation (Francesconi et al. 1972). Apparently amino acid homoeostasis differed between the $\mathrm{Zn}$-deficient and the control rats.

Possibly the levels of amino acids in plasma of the $\mathrm{Zn}$-deficient rats were affected by abnormalities in amino acid utilization or excretion. Hove et al. (1937) suggested that in $\mathrm{Zn}$-deficient rats the utilization of absorbed nitrogenous products is less efficient. This phenomenon apparently is generally true. $\mathrm{Zn}$ deficiency in tomatoes inhibits protein synthesis (Wood \& Sibly, 1952) and free amino acids accumulate (Possingham, 1956). Zn 
is required for protein synthesis in Euglena gracilis (Wacker, 1962) and Rhizopus nigricans (Wegner \& Romano, 1963). Zn deficiency inhibits incorporation of amino acids into the proteins of a number of rat tissues that differ in susceptibility (Macapinlac et al. 1966; Hsu et al. 1969 b; O'Neal et al. 1970; Hsu \& Woosely, 1972; McClain et al. 1973; Hsu et al. 1974; Duerre et al. 1977; Fosmire \& Sandstead, 1977). Possibly, the apparent homoeostatic changes and elevated levels of plasma histidine in our $\mathrm{Zn}$-deficient rats reflect impaired utilization of amino acids. Abnormalities that might contribute to depression of protein synthesis are depressed activity of RNA polymerase (EC 2.7.7.6) (Terhune \& Sandstead, 1972), abnormal formation or stability of polysomes (Fosmire $e t$ al. 1976) and possibly the production of an unusual RNA polymerase that can change the base content of the RNA produced, as was observed in E. gracilis (Falchuk et al. 1977). Apparently the rate of oxidation of some amino acids also was enhanced in zinc deficiency (Theuer \& Hoekstra, 1966; Hsu et al. 1969 a). Urinary excretion of ${ }^{35} \mathrm{~S}$ increased in zinc-deficient rats that were injected with [ ${ }^{35}$ S]methionine (Hsu \& Anthony, 1970), but the conversion of alanine to urea decreased (Griffith \& Alexander, 1972). Depressed urea synthesis is related to depressed activity of ornithine transcarbamylase (EC 2.1.3.3) (Burch et al. 1975) and, as a consequence, plasma ammonia (Prasad et al. 1978) may be elevated in $\mathrm{Zn}$-deficient animals. In our rats, however, the urea cycle apparently functioned normally as evidenced by the depression of plasma citrulline levels during $\mathrm{Zn}$ deficiency. Greeley (1979), however, found that plasma citrulline levels were significantly elevated in marginal $\mathrm{Zn}$ deficiency in pregnant rats, which might be explained by the extra stress of pregnancy.

Levels of tyrosine and tryptophan in plasma were correlated with their levels and the levels of catecholamines and serotonin respectively in the brain (Fernstrom \& Wurtman, 1971; Wurtman et al. 1974; Gibson \& Wurtman, 1978). The uptake of tyrosine or tryptophan by the brain is influenced by the relative values for tyrosine or tryptophan: other large neutral amino acids (Fernstrom et al. 1975; Fernstrom \& Faller, 1978). These relationships apparently have implications for the control of appetite. Anderson \& Ashley (1976) found that tyrosine:phenylalanine, but not tyrosine:neutral amino acids is correlated with energy intake and that tryptophan:neutral amino acids ratio is correlated with protein intake (Ashley \& Anderson, 1977). We found no significant differences among the experimental groups in tryptophan:other large neutral amino acids in plasma. Also, we found no relationship between food intake and either the tyrosine:phenylalanine or tyrosine: neutral amino acids in the plasma of $\mathrm{Zn}$-deficient rats.

Our findings suggest that in $\mathrm{Zn}$-deficient rats levels of plasma tyrosine, tryptophan and other large neutral amino acids are correlated with the intake of food, but tyrosine or tryptophan: other large neutral amino acids is not. In fact, many of the differences in the plasma amino acids in the $\mathrm{Zn}$-deficient rats between the top and bottom of the feeding cycle resembled differences in plasma amino acids between the $A L$ and $O F$ control rats. These variations in plasma amino acid concentrations appear to be a consequence, rather than a controlling mechanism, of food intake. In our $\mathrm{Zn}$-deficient rats only glutamic acid and histidine deviated from this pattern. Plasma glutamic acid was depressed and histidine was elevated during $\mathrm{Zn}$ deficiency. Our findings do not support the hypothesis that appetite control is mediated by changes in plasma amino acid concentrations but do suggest that Zn deficiency per se directly affects appetite.

This investigation was supported in part by the United States Department of Agriculture Cooperative Agreement No. 12-14-3001-294.

Mention of a trademark or proprietary product does not constitute a guarantee or warranty of the product by the U.S. Department of Agriculture, and does not imply its approval to the exclusion of other products that may also be suitable. 


\section{REFERENCES}

Allen, K. G. D., Klevay, L. M. \& Springer, H. L. (1977). Nutr. Rep. int. 16, 227.

Anderson, G. H. (1977). Adv. Nutr. Res. 7, 145.

Anderson, G. H. \& Ashley, D. V. M. (1976). Proc. Can. Fedn Biol. Soc. 19, 24.

Anonymous (1978). Nutr. Rev. 36, 343.

Apgar, J. (1972). J. Nutr. 102, 343.

Apgar, J. (1975). J. Nutr. 105, 1553.

Ashley, D. V. M. \& Anderson, G. H. (1977). Fedn Proc. Fedn Am. Socs exp. Biol. 36, 4665.

Bloxam, D. L. \& Warren, W. H. (1974). Analyt. Biochem. 60, 621.

Boquist, L. \& Lernmark, A. (1969). Acta Path. Microbiol. scand. 76, 215.

Burch, R. E., Williams, R. V., Hahn, H. K. J., Jetton, M. M. \& Sullivan, J. F. (1975). Clin. Chem. $21,568$.

Chesters, J. K. \& Quarterman, J. (1970). Br. J. Nutr. 24, 1061.

Curzon, G. \& Knot, P. J. (1974). Br. J. Pharmacol. 50, 197.

Cuthbertson, D. P., Fell, G. S., Smith, C. M. \& Tilstone, W. J. (1972). Br. J. Surg. 59, 925.

Denckla, W. D. \& Dewey, H. K. (1967). J. Lab. clin. Med. 69, 160.

Doumas, B. T. \& Biggs, H. G. (1972). In Siandard Methods of Clinical Chemistry, vol. 7, p. 175 [G. R. Copper, editor]. New York: Academic Press.

Duerre, J. A., Ford, K. M. \& Sandstead, H. H. (1977). J. Nutr. 107, 1082.

Falchuk, K. H., Hardy, C., Ulpino, L. \& Vallee, B. L. (1977). Biochem. Biophys. Res. Commun. 77, 314.

Fernstrom, J. D. \& Faller, D. V. (1978). J. Neurochem. 30, 1531.

Fernstrom, J. D., Faller, D. V. \& Shabshelowitz, H. (1975). J. Neural Trans. 36, 113.

Fernstrom, J. D., Larin, F. \& Wurtman, R.J. (1973). Life Sci. 13, 517.

Fernstrom, J. D. \& Wurtman, R. J. (1971). Science N.Y. 174, 1023.

Fosmire, G. J., Fosmire, M. A. \& Sandstead, H. H. (1976). J. Nutr. 106, 1152.

Fosmire, G. J. \& Sandstead, H. H. (1977). Proc. Soc. exp. Biol. Med. 154, 351.

Francesconi, R. P., Colter, R. \& Mager, M. (1972). J. Nutr. 102, 597.

Gibson, C. J. \& Wurtman, R. J. (1978). Life Sci. 22, 1399.

Greeley, S. (1979). Marginal zinc nutriture in the pregnant rat: effects on certain aspects of metabolism. PhD

Dissertation, Biochemistry Department, School of Medicine, University of North Dakota.

Griffith, P. R. \& Alexander, J. C. (1972). Nutr. Rep. int. $6,9$.

Henry, R. W. \& Elmes, M. E. (1975). Br. Med. J. iv, 625.

Hove, E., Elvehjem, C. A. \& Hart, E. B. (1937). Am. J. Physiol. 119, 768.

Hsu, J. M. \& Anthony, W. L. (1970). J. Nutr. 100, 1189.

Hsu, J. M., Anthony, W. L. \& Buchanan, P. J. (1969a). J. Nutr. 97, 279.

Hsu, J. M., Anthony, W. L. \& Buchanan, P. J. (1969b). J. Nutr. 99, 425.

Hsu, J. M., Kim, K. M. \& Anthony, W. L. (1974). Adv. exp. Med. Biol. 48, 347.

Hsu, J. M. \& Woosely, R. L. (1972). J. Nutr. 102, 1181.

Huber, A. M. \& Gershoff, S. N. (1973). J. Nutr. 103, 1739.

Kadish, A. H., Litle, R. L. \& Sternberg, J. C. (1968). Clin. Chem. 14, 116.

Luecke, R. W., Olman, M. E. \& Baltzer, B. V. (1968). J. Nutr. 94, 344.

Macapinlac, M. P., Pearson, W. N. \& Darby, W. J. (1966). In Zinc Metabolism, p. 142 [A. S. Prasad, editor]. Springfield, Ill.: C. C. Thomas.

McClain, P. E., Wiley, E. R., Beecher, G. R., Anthony, W. L. \& Hsu, J. M. (1973). Biochim. biophys. Acta 304, 457.

McConnell, S. D. \& Henkin, R. I. (1974). J. Nutr. 104, 1108.

McKenzie, J. M., Fosmire, G. J. \& Sandstead, H. H. (1975). J. Nutr. 105, 1466.

Mills, C. F., Quarterman, J., Chesters, J. K., Williams, R. B. \& Dalgarno, A. C. (1969). Am. J. clin. Nutr. $22,1240$.

O'Neal, R. M., Pla, G. W., Fox, M. R. S., Gibson, F. S. \& Fry, B. E. Jr (1970). J. Nutr. 100, 491.

Pardridge, W. M. (1977). J. Neurochem. 28, 103.

Peng, Y. \& Harper, A. E. (1970). J. Nutr. 100, 429.

Possingham, J. V. (1956). Aust. J. biol. Sci. 9, 539.

Prasad, A. S., Rabbani, P., Abbas, A., Bowersox, E. \& Fox, M. R. S. (1978). Ann. intern. Med. $89,483$.

Quarterman, J., Mills, C. F. \& Humphries, W. R. (1966). Biochem. Biophys. Res. Commun. 25, 354.

Spencer, H. \& Samachson, J. (1970). In Trace Element Metabolism in Animals, p. 312 [C. F. Mills, editor]. Edinburgh: Livingstone.

Tagliamonte, A., Biggio, G., Vargiu, L. \& Gessa, G. L. (1973). Life Sci. 12, 277.

Terhune, M. W. \& Sandstead, H. H. (1972). Science N.Y. 177, 68.

Tews, J. K., Kim, Y.-W. L. \& Harper, A. E. (1979). J. Nutr. 109, 304.

Theuer, R. C. \& Hoekstra, W. G. (1966). J. Nutr. 89, 448.

Todd, W. R., Elvehjem, C. A. \& Hart, E. B. (1934). Am. J. Physiol. 107, 146.

Wacker, W. E. C. (1962). Biochemistry N.Y. 1, 859.

Wegner, W. S. \& Romano, A. H. (1963). Science N.Y. 142, 1669.

Wilkins, P. J., Grey, P. C. \& Dreosti, I. E. (1972). Br. J. Nutr. $27,113$.

Wood, J. G. \& Sibly, P. M. (1952). Aust. J. Sci. Res. 5B, 244.

Wurtman, R. J., Larin, F., Mostafapour, S. \& Fernstrom, J. D. (1974). Science N. Y. 185, 183. 